\section{Earlier detection of glomerular dysfunction in $\beta$-thalassemia major patients}

\author{
Waseem F. Al-Tameemi, ${ }^{1}$ \\ Zainab M.J. Altawry² \\ ${ }^{1}$ Department of Medicine (Hematology), \\ College of Medicine, Al-Nahrain \\ University; ${ }^{2}$ Section of clinical \\ Hematology, Baghdad Teaching hospital, \\ Medical City Complex, Iraq
}

\begin{abstract}
Chronic transfusions program in $\beta$-thalassemia patients will inevitably lead to iron overload with a significant morbidity and mortality. Glomerular filtration rate (GFR) is progressively declined in relation to iron overload as well as chronic anemia. Objective is to define levels of Cystatin $\mathrm{C}$ in transfusion dependent $\beta$-thalassemia major patients as a sensitive marker for detection of earlier glomerular dysfunction in addition to understand the effect of iron overload ,chelating therapy and hepatitis infection. A cross sectional study conducted at Al-Basrah Hemoglobinopathy Centre for the period from September 2017 to January 2018 to enroll $75 \beta$-thalassemia major patients. Data collected included duration of the disease, total transfusion requirement, details of chelation therapy and its therapeutic index. In addition to blood urea, serum creatinine and Cystatin $\mathrm{C}$ with estimated GFR (eGFR). The mean Cystatin C was $1.075 \mathrm{mg} / \mathrm{L}$ where $66.6 \%$ of patients had abnormal renal function which is higher proportion than those with renal $(42.6 \%)$ detected according to serum creatinine level Cystatin $\mathrm{C}$ was significantly higher in patients who received desferrioxamine as compared to those received deferasirox $(\mathrm{P}=0.007)$, in accordance with GFR which is significantly higher in patients receiving the latter chelation therapy $(\mathrm{P}=0.009)$. A significant inverse relationship between Cystatin C, and GFR, while positive relationship between ferritin and Cystatin $\mathrm{C}$ ( $\mathrm{P}=0.0001,0.001$ respectively). Cyctatin $\mathrm{C}$ is better for detection and monitoring of glomerular dysfunction in B thalassemia major patient which is already not uncommon complications for the disease and iron chelation therapy.
\end{abstract}

\section{Introduction}

$\beta$-thalassemias are a group of autosomal recessive hereditary hemoglobinopathies, characterized by quantitative deficiency of beta-globin chains, ineffective erythropoiesis, and anemia. ${ }^{1}$

In Iraq, the prevalence of thalassemia had increased from 33.5/100,000 in 2010 to $37.1 / 100,000$ in 2015 , while the incidence rate had decreased from 72.4/100,000 live births to $34.6 / 100,000$ live births between 2010 and $2015 .^{2}$

Chronic transfusions program will inevitably lead to iron overload. The cumulative effects of iron overload lead to significant morbidity and mortality, if untreated. ${ }^{3}$

When serum transferrin saturation exceeds $70 \%$, free iron species - have been found in the plasma. These iron species are mainly responsible for generating reactive oxygen species with eventual tissue damage, organ dysfunction, and death. ${ }^{4}$

Iron chelation therapy has proven to be the only option to reduce morbidities and prolong survival into the fourth and fifth decades of life. ${ }^{4}$

Chronic anemia and hypoxia as well, are associated with oxidative stress and lipid peroxidation that are correlated to functional abnormalities in tubular cells of renal system. ${ }^{5}$

A negative correlation between serum ferritin levels and glomerular filtration rate (GFR), has been reported in patients with $\beta$ thalassemia major. ${ }^{6}$ Additional factors that contribute to a decreased GFR in these patients include transfusion-related hepatitis $\mathrm{B}$ or $\mathrm{C}$ virus or HIV infections leading to glomerulonephritis, as well as iron-induced hepatic and cardiac dysfunction. ${ }^{7}$

Serum creatinine is less reliable for making therapeutic decisions in critically ill patients. $^{8}$

Serum Cystatin C is a non-glycosylated, 13.3-kDa protein belonging to Cystatin $\mathrm{C}$ protease inhibitors. It is produced at a constant rate by all nucleated cells, freely filtered by the glomeruli, minimally bound to proteins, and totally reabsorbed and metabolized in the proximal tubule. ${ }^{9}$ It represents an early indication of renal impairment, possibly superior to serum creatinine. ${ }^{8}$ Concentration of serum cystatin $\mathrm{C}$ is not affected by gender, age, race, protein intake, and muscle mass, unlike serum creatinine. When GFR decreases, cystatin C level begins to rise proportionately. ${ }^{10}$ Confidence in the use of Cystatin C-based eGFR has increased since the 2012 Kidney Disease Improving Global Outcomes (KDIGO) guideline was published; results of a large meta-analysis show that Cystatin C-based eGFR detects increased risk of adverse outcomes that is not detected by creatininebased eGFR. ${ }^{11}$
Correspondence: Waseem F. Al-Tameemi, Department of Medicine (Hematology), College of Medicine, Al-Nahrain University, P.O. Box 70044, Iraq.

Tel.: +964.7901555115 .

E-mail: drwaseem72@gmail.com

Key words: $\beta$-thalassemia major; iron overload; chelation therapy; Cystatin C; glomerular filtration rate.

Acknowledgments: the authors would like to thank the patients participating in this research.

Contributions: all the authors made a substantive intellectual contribution, performed part of the experiments. All the authors have read and approved the final version of the manuscript and agreed to be accountable for all aspects of the work.

Conflict of interest: the authors declare no potential conflict of interest

Availability of data and materials: All data generated or analyzed during this study are included in this published article.

Informed consent: Verbal consents had been taken from all patients under approval of IRB rules.

Received for publication: 3 April 2020.

Accepted for publication: 7 April 2020

This work is licensed under a Creative Commons Attribution 4.0 License (by-nc 4.0)

(Copyright: the Author(s), 2020

Licensee PAGEPress, Italy

Thalassemia Reports 2020; 10:9007

doi:10.4081/thal.2020.9007

\section{Objectives}

The objectives were: i) to define levels of Cystatin $C$ in transfusion dependent $\beta$ thalassemia major patients as a sensitive marker for detection of earlier glomerular dysfunction in relation to estimated GFR; ii) to evaluate the effect of iron overload ,chelating therapy and hepatitis infection on Cystatin C level.

\section{Materials and Methods}

A cross sectional study conducted at $\mathrm{Al}-$ Basrah hemoglobinopathy Centre for the period from September 2017 to January 2018. Seventy-five $\beta$-thalassemia major patients were enrolled in the study, and assessed during their regular follow up for iron chelation therapy and blood transfusions. They had no clinical or laboratory evidence of renal impairment at time of 
study. Verbal consents had been taken from all patients under approval of IRB rules.

Those who known to have renal failure, heart failure, longstanding diabetes mellitus, active infection or malignancy were excluded. For each patient, both demographic and clinical data were recorded like - age, sex, body mass index, duration of the disease, total transfusion requirement, type of chelation therapy, the dose and its therapeutic index, in addition to hepatitis $\mathrm{C}, \mathrm{B}$ virology status. Therapeutic index calculated according to Daily dose ( $\mathrm{mg} / \mathrm{kg}$ ) / current serum ferritin $(\mu \mathrm{g} / \mathrm{L}) .{ }^{12}$ At same time other laboratory parameters were registered like (Hemoglobin level, blood urea, serum creatinine, ferritin and Cystatin C). Estimated glomerular filtration rate (eGFR) was calculated by using CKD-EPI Cystatin and Creatinine 2012 equation adjusted for age, sex, and race: ${ }^{13}$

eGFR $=177.6 \times \mathrm{SCr}^{-0.63} \times \mathrm{CysC}^{-0.57} \times$ age $^{-0.20}$

$\times 0.80$ (if female)

$\times 1.11$ (if African American)

eGFR (estimated glomerular filtration rate) $=\mathrm{mL} / \mathrm{min} / 1.73 \mathrm{~m}^{2}$

$\mathrm{S}_{\mathrm{Cr}}($ serum creatinine $)=\mathrm{mg} / \mathrm{dL}$

$\mathrm{S}_{\text {cys }}($ standardized serum cystatin $\mathrm{C})=\mathrm{mg} / \mathrm{l}$, age $=$ years .

Pretransfusion hemoglobin level between (9.5-10.5 g/dL) was arbitrarily considered achievable target for TM patients, ${ }^{12}$ other parameters were considered normal according to the following cutoffs: serum creatinine $(50-110 \mu \mathrm{mol} / \mathrm{L}$ or $0.6-1.2$ $\mathrm{mg} / \mathrm{dL})$, blood urea $(4-8.2 \mu \mathrm{mol} / \mathrm{L}$ or $24-50$ $\mathrm{mg} / \mathrm{dL}),{ }^{14}$ and the patients were grouped according to serum ferritin into two groups, $>1000 \mu \mathrm{g} / \mathrm{L},<1000 \mu \mathrm{g} / \mathrm{L}$, on the bases that it is the target level to start chelation therapy. ${ }^{12}$

Renal dysfunction was defined as eGFR $<90 \mathrm{~mL} / \mathrm{min} / 1.73 \mathrm{~m}^{2}$, and/or abnormally elevated serum Cystatin $\mathrm{C}$ according to the reference ranges $(\mathrm{mg} / \mathrm{L})$ for age $\leq 50$ year (male: 0.31-0.79 and female: 0.40-0.99) and for age $>50$ year (for both :0.40-0.99)..$^{15}$

Data were analyzed with IBM SPSS statistical package for windows version 23 (SPSS Inc. Chicago, Illinois, USA). They expressed as mean \pm standard deviation (SD), while categorical data were expressed as frequencies and percentages. Chi-square test was used to study the correlation between the variables, and T-test for testing the significant differences $\mathrm{P}$ value of $\leq 0.05$ is considered significant, and $\mathrm{P}$ value $<0.001$ is considered highly significant.

\section{Results}

The female: male ratio of (1.08:1), their age ranged between 16-43year with mean age $21.9 \pm 6.1$ year. The mean transfusion requirement was 23.5 units/year ranged between (12-34), over their disease durations that ranged between (8-35) years as in Table 1.

Table 1. Demographic data of $\beta$-thalassemia major.

\begin{tabular}{lcccc}
\hline Variable & \multicolumn{2}{c}{ Frequency or range } & Mean \pm SD \\
Age (year) & \multicolumn{2}{c}{$16-43$} & & $21.9 \pm 6.1$ \\
& Male & & $16-43$ & $23.5 \pm 7.28$ \\
& Female & & $17-34$ & $20.5 \pm 4.5$ \\
Transfusion requirement (units/year) & & $12-34$ & & $23.5 \pm 5.8$ \\
& Male & & $12-34$ & $23.8 \pm 6.3$ \\
& Female & & $13-30$ & $23.5 \pm 5.5$ \\
\hline Disease duration (years) & & $8-35$ & & $15.8 \pm 5.5$ \\
& Male & & $10-35$ & $16.5 \pm 6.7$ \\
& Female & & $8-22$ & $14.74 \pm 4.09$ \\
Type of chelation (number of patients) & & & & \\
Desferrioxamine No. (\%) & & $35(47 \%)$ & & - \\
Deferasirox No. (\%) & & $40(53 \%)$ & & \\
\hline
\end{tabular}

Table 2. Laboratory data.

\begin{tabular}{|c|c|c|c|c|}
\hline Variable & & Range & & $($ mean \pm SD $)$ \\
\hline Hemoglobin(g/dL) & $\begin{array}{c}\text { Male } \\
\text { Female }\end{array}$ & $5.4-10.3$ & $\begin{array}{c}5.6-9.7 \\
5.4-10.3\end{array}$ & $\begin{array}{c}7.7 \pm 0.9 \\
7.78 \pm 0.8 \\
7.72 \pm 1.06\end{array}$ \\
\hline Blood urea $(\mu \mathrm{mol} / \mathrm{L})$ & $\begin{array}{c}\text { Male } \\
\text { Female }\end{array}$ & $4-6.2$ & $\begin{array}{l}4-6.1 \\
4-6.2 \\
\end{array}$ & $\begin{array}{c}5.50 \pm 4.4 \\
7.50 \pm 3.4 \\
5.50 \pm 1.43\end{array}$ \\
\hline Creatinine $(\mu \mathrm{mol} / \mathrm{L})$ & $\begin{array}{c}\text { Male } \\
\text { Female }\end{array}$ & $60-98$ & $\begin{array}{l}63-98 \\
62-93\end{array}$ & $\begin{array}{c}77.30 \pm 7.5 \\
77.74 \pm 8.32 \\
76.20 \pm 6.4\end{array}$ \\
\hline Ferritin $(\mu \mathrm{g} / \mathrm{L})$ & $\begin{array}{c}\text { Male } \\
\text { Female }\end{array}$ & $540-7600$ & $\begin{array}{c}1000-7600 \\
540-7000\end{array}$ & $\begin{array}{l}2111 \pm 1784 \\
2181 \pm 1918 \\
2023 \pm 1693 \\
\end{array}$ \\
\hline Cystatin C (mg/L) & $\begin{array}{c}\text { Male } \\
\text { Female }\end{array}$ & $0.64-1.99$ & $\begin{array}{l}0.64-1.98 \\
0.64-1.99\end{array}$ & $\begin{array}{l}1.07 \pm 0.26 \\
1.10 \pm 0.26 \\
1.01 \pm 0.20\end{array}$ \\
\hline GFR $\left(\mathrm{mL} / \mathrm{min} / 1.73 \mathrm{~m}^{2}\right)$ & $\begin{array}{c}\text { Male } \\
\text { Female }\end{array}$ & $53-115$ & $\begin{array}{l}58-115 \\
53-115\end{array}$ & $\begin{array}{c}91.3 \pm 14 \\
97.3 \pm 16.2 \\
89.0 \pm 14.4\end{array}$ \\
\hline
\end{tabular}

Table 3. Relationship of laboratory data with different lines of treatment.

\begin{tabular}{lcccc} 
Biochemical marker & Line of treatment & No. & MeantSD & P value \\
Bloodurea $(\mu \mathrm{mol} / \mathrm{L})$ & Deferasirox & 39 & $4.94 \pm 0.6$ & 0.43 \\
& Desferrioxamine & 36 & $5.06 \pm 0.7$ & \\
Creatinine $(\mu \mathrm{mol} / \mathrm{L})$ & Deferasirox & 39 & $76.64 \pm 8.3$ & 0.09 \\
& Desferrioxamine & 36 & $76.84 \pm 6.3$ & \\
\hline Cystatin C $(\mathrm{mg} / \mathrm{L})$ & Deferasirox & 39 & $0.99 \pm 0.16$ & $0.007^{*}$ \\
& Desferrioxamine & 36 & $1.14 \pm 0.28$ & \\
GFR $\left(\mathrm{mL} / \mathrm{min} / 1.73 \mathrm{~m}^{2}\right)$ & Deferasirox & 39 & $97.31 \pm 14$ & $0.009^{*}$ \\
& Desferrioxamine & 36 & $87.78 \pm 15$ & \\
\hline
\end{tabular}

*P value of $<0.05$ is considered significant,
Thirty-five patients $(47 \%)$ were receiving desferrioxamine (desferal $\left.{ }^{\circledR}\right)$, while the remaining 40 patients $(53 \%)$ were kept on $(20-40 \mathrm{mg} / \mathrm{kg})$ and $(30-40 \mathrm{mg} / \mathrm{kg})$ per day respectively. Nearly all patients who receiving desferrioxamine, had an expected therapeutic index $<0.025$. Table 2 reveal that all patients had apparentdeferasirox (Exjad $\left({ }^{\circledR}\right)$ with dose of

The laboratory data which are shown in 
ly normal renal functions, with lower GFR in female than in male, the minimum GFR was $53 \mathrm{~mL} / \mathrm{min} / 1.73 \mathrm{~m}^{2}$, and maximum 115 $\mathrm{mL} / \mathrm{min} / 1.73 \mathrm{~m}^{2}$. Thirty-two patients (42.6\%) had impaired renal function according to eGFR $<90 \mathrm{~mL} / \mathrm{min} / 1.73 \mathrm{~m}^{2}$.

The mean Cystatin C was $1.075 \mathrm{mg} / \mathrm{L}$ ranged between (0.64-1.99). Fifty patients (66.6\%) had abnormal level indicating that there were higher proportion of patient having an impaired renal function than those detected by calculation of eGFR.

The maximum ferritin level was 7600 $\mu \mathrm{g} / \mathrm{L}$, while the minimum was $540 \mu \mathrm{g} / \mathrm{L}$. Sixty patients $(79.7 \%)$ had serum ferritin $>1000 \mu \mathrm{g} / \mathrm{L}$, nineteen patients of them were $\mathrm{HCV}$ positive, with statistically significant positive relation between them $(\mathrm{P}=0.04)$, as shown in Figure 1.
Cystatin C was significantly higher in patients who received desferrioxamine as compared to those received deferasirox $(\mathrm{P}=0.007)$, as shown in Figure 2, in accordance with GFR which is significantly higher in patients receiving the latter chelation therapy ( $\mathrm{P}=0.009)$, as shown in Table 3 .

The results showed significant inverse relationship between Cystatin C, and GFR, while positive relationship between ferritin and Cystatin $\mathrm{C}(\mathrm{P}=0.0001,0.001$ respectively), also there were significant positive relationship between Cystatin $\mathrm{C}$ and number of blood transfusion/year, $(\mathrm{P}=0.001)$.

No significant correlations were found between Cystatin C, blood urea, serum creatinine, ( $p$ value $0.43,0.09$ ) respectively as well as no significant correlation with sex, BMI ( $\mathrm{P}=0.1,0.15$ respectively), however

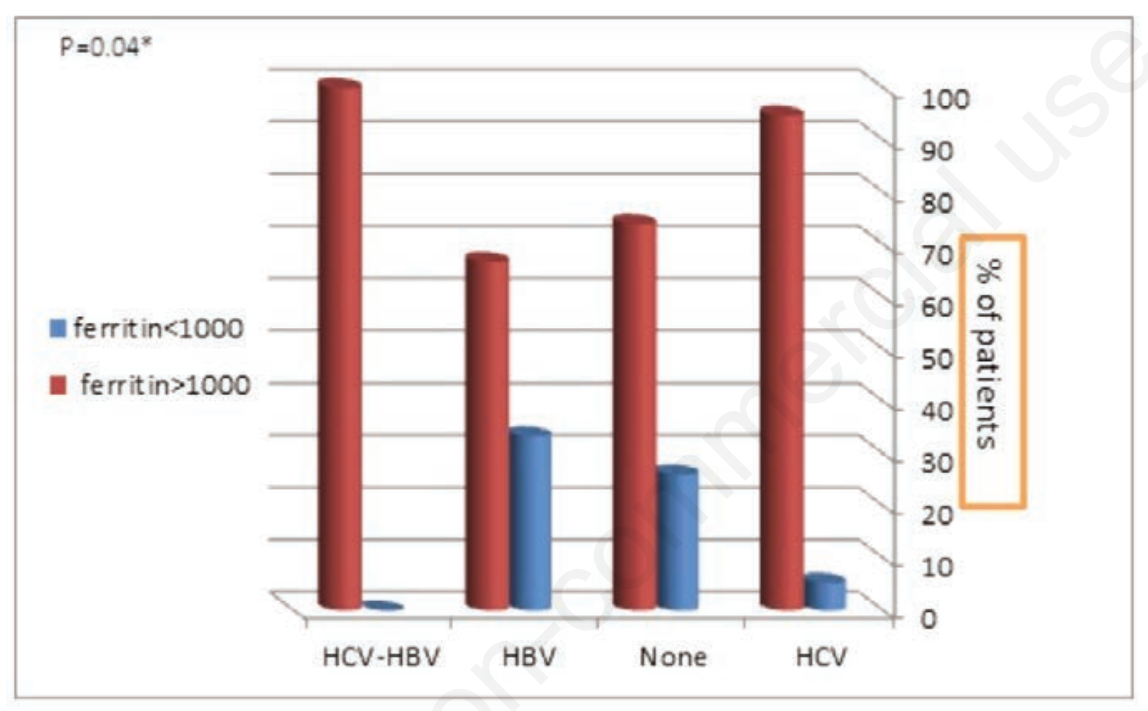

Figure 1. Diagrammatic representation of virology status versus ferritin level.

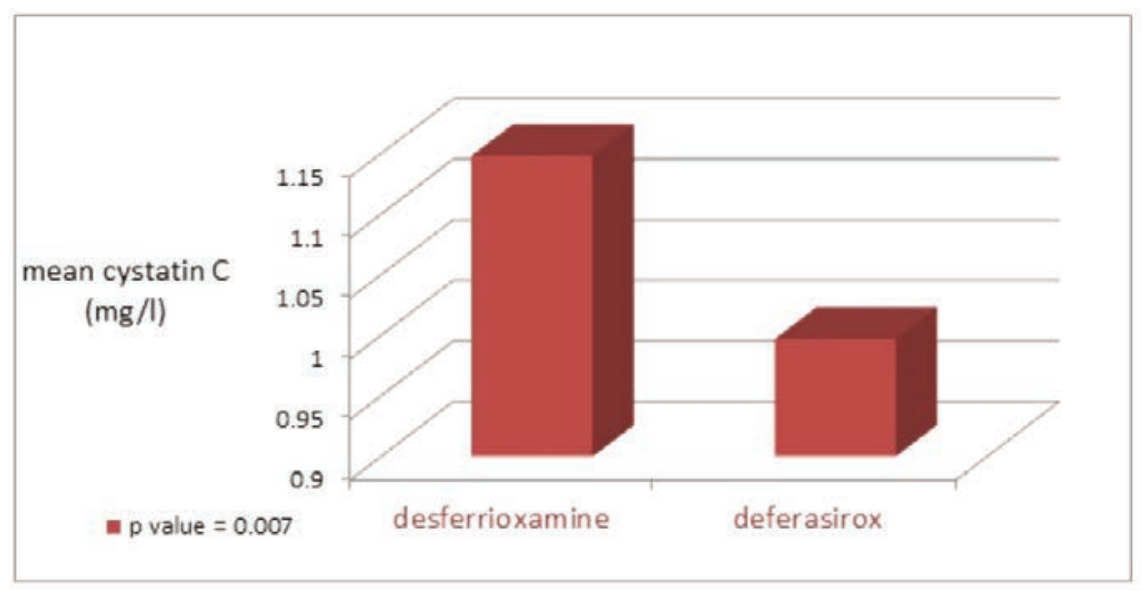

Figure 2. Mean cystatin C level according to line of treatment. there is significant correlation with age $(\mathrm{P}=0.01)$.

\section{Discussion}

The mechanism of renal dysfunctions in patients with $\beta$-thalassemia major is multifactorial, resulted mainly from long-standing anemia, chronic hypoxia, iron overload and desferrioxamine toxicity. ${ }^{12,14}$ The present study - demonstrated that $66.6 \%$ of $\beta$ thalassemia major patients had abnormally high serum Cystatin $\mathrm{C}$ level, which may indicate- that Cystatin $\mathrm{C}$ is more sensitive marker for early detection of glomerular dysfunction.

It is also shown that there was no statistically significant relation between Cystatin $\mathrm{C}$ level, blood urea and serum creatinine $(\mathrm{P}=0.43,0.09)$ respectively, and that is why the routine investigation can't be more reliable parameter for assessment of renal function in case of use nephrotoxic medication in Thalassemia Major patients .

Cystatin $\mathrm{C}$ has characteristic independency on BMI and sex $(\mathrm{P}=0.1,0.15$ respectively), which makes it superior on serum creatinine., which is in agreement with the results of Banfi $\mathrm{G}$ et al. ${ }^{16}$ study, and Hannemann A et al. ${ }^{17}$ Cystatin C level did not correlate statistically with sex, BMI. These results were compatible with Papassotiriou et al..$^{18}$ results , but contrasted with Groesbeck et al. ${ }^{19}$ who found statistically significant differences between genders, with men having higher Cystatin $\mathrm{C}$ levels than women.

A significant correlation found between cystatin $\mathrm{C}$ and age in this study $(\mathrm{P}=0.01)$, in contrast with Papassotiriou et al., ${ }^{18}$ who assumed that there is no significant relation between Cystatin $\mathrm{C}$ and age, There is an inevitable decline in renal function with age even in healthy people, due progressive loss of nephrons with aging, and Cystatin $\mathrm{C}$ is freely filtered by the glomeruli, and totally reabsorbed by proximal tubules, hence it's level increased with age. This significant relationship was supported also by Groesbeck D et al. ${ }^{19}$ and Delanaye $\mathrm{P}$ et al ${ }^{20}$

\section{Conclusions}

The results showed highly significant inverse relationship between Cystatin $\mathrm{C}$ and GFR $(\mathrm{P}<0.000)$, despite normal range of conventional biochemical parameters(blood urea and serum creatinine), the results were coming in agreement with Ali and Mahmoud et al. ${ }^{21}$ These results support the idea that cystatin $\mathrm{C}$ gives a good estimate of 
GFR, more accurate and precise than other methods. ${ }^{21}$ This significant decline in eGFR over time suggesting that tubular damage acquired in childhood caused by either TM or its treatment may eventually result in abnormal eGFR. ${ }^{22}$

Positive highly significant relationship were found in the present study between Cystatin $\mathrm{C}$ and serum ferritin, the transfusion requirement(units/year), and disease duration (years) $(\mathrm{P}<0.001$ for all), that may indicate the effect of iron overload in increasing the risk of renal impairment .These results are in accordance with Papassotiriou et al. ${ }^{18}$ Ali and Mahmoud et al. ${ }^{21}$ and Eliana Lai. ${ }^{22}$

Regarding the type of chelation therapy, Cystatin C level significantly higher in those kept on desferrioxamine $(\mathrm{P}=0.007)$, as compared to deferasirox chelation therapy, in accordance with GFR that is significantly higher in patients receiving the later $(\mathrm{P}=0.009)$, and this is expected as the former chelation therapy is mainly renal excreted, and overdosing is predicted possibly because of administration pump malfunction and inadequate dosage monitoring. ${ }^{23}$

In conclusion it can be recommended to use Cyctatin $\mathrm{C}$ for earlier detection and follow up of glomerular dysfunction in B thalassemia major patient as it is an accurate, sensitive endogenous marker keeping in mind that this complication is not an uncommon in those patients that may aggravated by iron overload and iron chelation therapy.

\section{References}

1. Weatherall DJ. The Thalassemias: Disorders of globin synthesis. In: Kenneth Kaushansky, MD,MACP. William Text Book of Hematology, 9th ed. New York: McGrow Hill; 2016. pp 751.

2. Kadhim KA, Baldawi KH, Lami FH. Prevalence, incidence, trend, and complications of thalassemia in Iraq. Hemoglobin 2017;41:164-8.
3. Cappellini MD. Exjade $($ (deferasirox, ICL670) in the treatment of chronic iron overload associated with blood transfusion. Ther Clin Risk Manage 2007;3: 291.

4. Ozment CP, Turi JL. Iron overload following red blood cell transfusion and its impact on disease severity. Biochim Biophys Acta (BBA)-Gener Subj 2009;1790:694-701.

5. Mallat NS, Mallat SG, Musallam KM, Taher AT. Potential mechanisms for renal damage in beta-thalassemia. J Nephrol 2013;26:821-8.

6. Lim CS, Vaziri ND. Iron and oxidative stress in renal insufficiency. Am J Nephrol 2004;24:569-75.

7. Ponticelli C, Musallam KM, Cianciulli P, Cappellini MD. Renal complications in transfusion-dependent beta thalassaemia. Blood Rev 2010;24:239-44.

8. Murty MS, Sharma UK, Pandey VB, Kankare SB. Serum cystatin $\mathrm{C}$ as a marker of renal function in detection of early acute kidney injury. Indian $\mathrm{J}$ Nephrol 2013;23:180.

9. Coresh J, Stevens L, Greene T, et al. Serum cystatin C GFR estimation equation: Pooled analysis of 3134 individuals. J Am Soc Nephrol 2006;17:189A.

10. Inker LA, Schmid $\mathrm{CH}$, Tighiouart $\mathrm{H}$, et al. Estimating glomerular filtration rate from serum creatinine and cystatin C. N Engl J Med 2012;367:20-9.

11. Inker LA, Astor $\mathrm{BC}$, Fox $\mathrm{CH}$, et al. KDOQI US commentary on the 2012 KDIGO clinical practice guideline for the evaluation and management of CKD. Am J Kidney Dis 2014;63:71335.

12. Vichinsky E, Bhatia S, Bojanowski J, et al. Standards of Care Guidelines for Thalassemia. Children's Hospital \& Research Center Oakland Hematology/ Oncology Department. Oakland, CA 94609; 2012:6. Available from: www.childrenshospitaloakland. org

13. Keller T, Messow CM, Lubos E, et al. Cystatin $\mathrm{C}$ and cardiovascular mortality in patients with coronary artery disease and normal or mildly reduced kidney function: results from the Athero Gene study. Eur Heart J 2009;30:314-20.

14. Levey AS, Eckardt KU, Tsukamoto Y, et al. Definition and classification of chronic kidney disease: a position statement from Kidney Disease: Improving Global Outcomes (KDIGO). Kidney Int 2005;67:2089-100.

15. Willems D, Wolff F, Mekhali F, Gillet C. Cystatin $\mathrm{C}$ for early detection of renal impairment in diabetes. Clin Biochem 2009;42:108-10.

16. Banfi G, Del Fabbro M. Relation between serum creatinine and body mass index in elite athletes of different sport disciplines. Br J Sports Med 2006; 40:675-8.

17. Hannemann A, Friedrich N, Dittmann $\mathrm{K}$, et al. Age-and sex-specific reference limits for creatinine, cystatin $\mathrm{C}$ and the estimated glomerular filtration rate. Clin Chem Lab Med 2012;50:919-26.

18. Papassotiriou I, Margeli A, Hantzi E, et al. Cystatin $C$ levels in patients with $\beta$ thalassemia during deferasirox treatment. Blood Cells Mol Dis 2010;44: 152-5.

19. Groesbeck D, Köttgen A, Parekh R, et al. Age, gender, and race effects on cystatin $\mathrm{C}$ levels in US adolescents. Clin J Am Soc Nephrol 2008;3:1777-85.

20. Delanaye P, Cavalier E, Saint-Remy A, et al. Discrepancies between creatinine-based and cystatin C-based equations in estimating prevalence of stage 3 chronic kidney disease in an elderly population. Scand J Clin Lab Investig 2009;69:344-9.

21. Ali BA, Mahmoud AM. Frequency of glomerular dysfunction in children with beta thalassaemia major. Sultan Qaboos Univ Med J 2014;14:e88.

22. Eliana Lai M, Spiga A, Vacquer S, et al. Renal function in patients with $\beta$-thalassaemia major: a long-term follow-up study. Nephrol Dialysis Transplant 2012;27:3547-51.

23. Hamed EA, ElMelegy NT. Renal functions in pediatric patients with beta-thalassemia major: relation to chelation therapy: original prospective study. Ital J Pediatr 2010; 36:39. 